\title{
JOB TENURE AND PENSION COVERAGE
}

\author{
Alicia H. Munnell, Kelly Haverstick, and Geoffrey Sanzenbacher
}

CRR WP 2006-18

Released: October 2006

Draft Submitted: October 2006

\author{
Center for Retirement Research at Boston College \\ 258 Hammond Street \\ Chestnut Hill, MA 02467 \\ Tel: 617-552-1762 Fax: 617-552-1750 \\ http://www.bc.edu/crr
}

* Alicia H. Munnell is the Director of the Center for Retirement Research (CRR) and the Peter F. Drucker Professor of Management Sciences at Boston College's Carroll School of Management. Kelly Haversstick is a research economist at the CRR. Geoffrey Sanzenbacher is a graduate research assistant at the CRR. The research reported herein was performed, in part, pursuant to a grant from the U.S. Social Security Administration (SSA) funded as part of the Retirement Research Consortium. The findings and conclusions expressed are soley those of the authors and do not represent the views of SSA, any agency of the Federal Government, or Boston College. The authors would like to thank JP Aubry for helpful research assistance.

(C) 2006, by Alicia H. Munnell, Kelly Haverstick, and Geoffrey Sanzenbacher. All rights reserved. Short sections of text, not to exceed two paragraphs, may be quoted without explicit permission provided that full credit, including (C) notice, is given to the source. 


\section{About the Center for Retirement Research}

The Center for Retirement Research at Boston College, part of a consortium that includes a parallel centers at the University of Michigan and the National Bureau of Economic Research, was established in 1998 through a grant from the Social Security Administration. The goals of the Center are to promote research on retirement issues, to transmit new findings to the policy community and the public, to help train new scholars, and to broaden access to valuable data sources. Through these initiatives, the Center hopes to forge a strong link between the academic and policy communities around an issue of critical importance to the nation's future.

\section{Center for Retirement Research at Boston College}

258 Hammond Street

Chestnut Hill, MA 02467

phone: 617- 552- 1762 fax: 617- 552- 0191

e-mail: crr@bc.edu

www.bc.edu/crr

Affiliated Institutions:

American Enterprise Institute

The Brookings Institution

Center for Strategic and International Studies

Massachusetts Institute of Technology

Syracuse University

Urban Institute 


\begin{abstract}
Commentators constantly cite an increase in labor mobility as a major reason for the shift in the private sector from defined benefit to defined contribution plans. But while most casual observers accept such a phenomenon, economists have been hard pressed to find any significant change over time. Only in recent years have the data indicated that mobility might have increased for some groups. This pattern suggests that the advent of 401(k) plans led to an increase in mobility rather than an increase in mobility leading to the proliferation of 401(k)s. This paper attempts to sort out this "chicken and egg” issue using data from the Current Population Survey (CPS) and the 1984 through 2001 panels of the Survey of Income and Program Participation (SIPP).
\end{abstract}




\section{Introduction}

Commentators constantly cite an increase in labor mobility as a major reason for the shift in the private sector from defined benefit to defined contribution plans. But while most casual observers accept such a phenomenon, economists have been hard pressed to find any significant change over time. Only in recent years have the data indicated that mobility might have increased for some groups. This pattern suggests that the advent of 401(k) plans led to an increase in mobility rather than an increase in mobility leading to the proliferation of 401(k)s. This paper attempts to sort out this “chicken and egg” issue.

Section I describes the nature of the shift from traditional defined benefit plans to 401(k)s. Section II summarizes how the shift occurred. Section III explores possible reasons on both the employer and employee side for the shift. Section IV presents evidence on tenure from the tenure supplements to the Current Population Survey and the 1984 through 2001 panels of the Survey of Income and Program Participation (SIPP). Section V provides data on retention rates from the tenure supplements. Section VI uses SIPP data to estimate the relationship between tenure and type of pension coverage. Section VII concludes.

The bottom line is that, whereas tastes regarding lifetime employment may have begun to shift in the early 1980s, tenure and mobility remained virtually unchanged until the mid-1990s. Therefore, it is very hard to argue that increased mobility explains the spread of 401(k) plans. Since the mid 1990s, tenure and retention rates have declined,

particularly for men over 45 who would have been most constrained from switching jobs in a defined benefit world. The SIPP data, which show that tenure depends importantly on the type of pension coverage, suggest that the shift to 401(k) plans may have caused a reduction in median tenure among older workers. Thus, the egg (401(k) plans) came first and then the chicken (increased mobility).

\section{Pension Coverage and Mobility}

The nature of pension coverage has shifted dramatically in the last two decades. Twenty years ago, most people with pension coverage had a traditional defined benefit 
plan that paid benefits at retirement in the form of a lifetime annuity - often a percentage of final salary for each year of service. The employer finances these benefits by making pre-tax contributions into a pension fund; employees typically do not contribute. The employer holds the assets in trust, directs the investments, and bears the risk. The Pension Benefit Guaranty Corporation (PBGC) insures benefits up to specified limits. ${ }^{1}$

Today the world looks very different. Most people with pensions have a defined contribution plan - most often a 401(k). In contrast to defined benefit plans, defined contribution plans are like savings accounts. Generally the employee, and often the employer, contributes a specified percentage of salary into the account. These contributions are invested, usually at the direction of the employee, mostly in mutual funds consisting of stocks and bonds. Upon retirement, the worker generally receives the balance in the account as a lump sum, albeit with the option to roll it over to an IRA.

Defined benefit plans and 401(k)s would be expected to have a very different effect on worker mobility. ${ }^{2}$ The original purpose of defined benefit plans was to encourage long tenure and efficient retirement. Since accrued pension benefits based on final earnings increase rapidly as job tenures lengthen and then decline as early retirement incentives fade out (see Figure 1), defined benefit plans motivate workers to remain with the firm and then retire. Workers with final earnings defined benefit plans

\footnotetext{
${ }^{1}$ The PBGC monthly guarantee limit in 2006 is \$3,972 at age 65, and declines to \$1,787 at age 55. Employers pay for this insurance with premiums largely determined by the plan's funding status.

${ }^{2}$ The following discussion refers to 'traditional' defined benefit plans. During the 1990s, many employers converted their traditional defined benefit plans to cash balance plans. As in traditional defined benefit plans, the employer makes the contributions, owns the assets, selects the investments, and bears the risk. The PBGC also insures the benefits. To the employee, however, cash balance plans look very much like defined contribution plans. The employer typically contributes 4 or 5 percent of the worker's pay to a "notional" account and provides an interest credit on the balances. Employees receive regular statements and generally withdraw the balance as a lump sum when they retire or terminate employment. Since these plans are not backloaded, employees suffer no loss in benefits as they move from job to job, and therefore would not be expected to affect mobility. Bank America created the first cash balance plan in 1985, and by 2003 these plans accounted for 22 percent of employees and 26 percent of assets in defined benefit plans (Buessing and Soto, 2006). Since 2003, extensive litigation has brought the expansion of cash balance plans to a virtual halt.
} 
who change jobs, even among firms with identical plans and immediate vesting, receive significantly lower benefits than workers with continuous coverage under a single plan.

The effect of mobility in a defined benefit plan that provides 1.5 percent of final earnings for each year of service is shown in Figure 2. With 3 percent inflation, the steady earner would receive a replacement rate at age 62 of 50 percent. If the employee switches jobs at age 45 , even to a firm with an identical plan, the replacement rate drops to 41 percent; if he changes jobs twice, the replacement rate drops to 37 percent. The reason job changers get lower replacement rates is because their benefits are based on earnings at the time they terminate employment. Workers who do not change have their pension credits applied to final earnings, which reflect inflation and productivity growth over their careers. ${ }^{3}$ The greater the rate of inflation, the greater the discrepancy between benefits based on wages at termination and those based on final earnings.

Defined contribution plans generally - and 401(k) plans in particular - are not a mechanism for retaining workers. As noted above, benefits accrue smoothly over the worker's lifetime; they are not "backloaded" as in traditional defined benefit plans. Once vested, workers do not forfeit any benefits when they change employers, and therefore 401(k) plans should not deter mobility in any way. Thus, commentators often suggest that increased mobility of U.S. workers is one factor that explains the shift in coverage from defined benefit plans to 401(k)s.

\section{The Mechanics of the Shift to 401(k) Plans}

The changing nature of pension coverage is shown in Figure 3. In 1980, 83 percent of private sector workers with pension coverage had either a defined benefit plan only or a defined benefit plan and a supplementary defined contribution plan. By the early 1990s, that percentage had declined to 57 percent, and in 2004 it was 39 percent.

\footnotetext{
${ }^{3}$ An example might help clarify. Consider a worker who is covered by a defined benefit plan that pays 1.5 percent of final earnings for each year of service. This worker, who starts work the company at age 30 and retires at age 62 earning $\$ 55,000$, would be entitled to an annual benefit at age 62 of $\$ 26,200$ per year (1.5 percent $x 32$ years $x \$ 55,000$ ). However, if that worker switched jobs at age 45 , when he was earning $\$ 35,000$, even to firm with an identical plan, he would have a combined benefit of only $\$ 20,900$. From his first employer, he would receive $\$ 7,875$ (1.5 percent x 15 years $x \$ 35,000$ ), and from his second employer $\$ 14,025$ (1.5 percent x 17 years x $\$ 55,000)$.
} 
Most workers today rely on 401(k) plans as their only source of employer-sponsored retirement saving. The question is how pension coverage moved from there to here.

The first point worth emphasizing is that - until the recent round of "pension freezes” - the actual shutting down of a defined benefit plan and opening of a 401(k) was an extremely rare event, particularly among large plans. ${ }^{4}$ One study (Ippolito 1999) carefully followed a sample of 249 defined benefit plans with at least 500 participants over the period 1987 through 1995; of the 249 original plans, 214 remained in 1995. Of the 35 that sponsors terminated, 3 were replaced by a new defined benefit plan; 14 by no new plan; and only 18 by a defined contribution plan. In other words, most participants in the original sample were still in a defined benefit plan at the end of the study; their employers did not replace their defined benefit plan with a $401(\mathrm{k}){ }^{5}$

Instead of conversions from defined benefit plans, initial coverage by 401(k)s resulted from the addition of $401(\mathrm{k})$ provisions to traditional thrift and profit-sharing plans in the early 1980s. This was an obvious move because thrift plans, which generally served as supplements to defined benefit plans, required employees to make after-tax contributions. Since 401(k) plans allowed pre-tax contributions, introducing a 401(k) provision meant employees could maintain their contribution level and see an increase in take-home pay. In the case of profit sharing plans, the shifts to 401(k)s and voluntary participation allowed employers to reduce the profits distributed to employees. About 30 percent of 401(k) participants in 1995 were in plans established before 1980 (see Table 1). Since 401(k) plans did not become popular until 1981, when the IRS issued clarifying regulations, a plan established before 1980 is generally presumed to be a thrift or profitsharing plan that was converted to a 401(k).

The second step in the growth of 401(k) coverage was a surge in new plan formation and termination in the 1980s. Figure 4 presents initial applications to the Internal Revenue Service (IRS) for determination letters, which is an imperfect but useful

\footnotetext{
${ }^{4}$ For a discussion of the factors underlying the recent rash of pension freezes, see Munnell et al (2006).

${ }^{5}$ These results are consistent with those of two other studies, Kruse (1995) and Papke et al. (1996), even though the various studies adopted different methodologies. The first tracked all pension plans from 1980 to 1986 using data from the Form 5500 and the second surveyed a sample of 401(k) plans in 1987 to see if they had replaced a defined benefit plan. In each case, the researchers found that most new 401(k) plans had not replaced a preexisting defined benefit plan.
} 
measure of plan formation. ${ }^{6}$ During the 1960s and into the 1970s, defined benefit and defined contribution plan formations grew in lock step. The picture then changed dramatically, and the formation of defined contribution plans took off. This surge continued through the 1980s, after the emergence of 401(k) plans. Referring back to Table 1, 45 percent of participants in 1995 were in plans that were created during the 1980s. A second surge in 401(k) plans occurred during the heyday of the 1990s.

The third factor in the shift to 401(k) coverage was a spike in defined benefit terminations during the late 1980s and early 1990s. Terminations increased sharply after the Tax Reform Act of 1986 placed restrictions on very small defined benefit plans that benefited only highly paid individuals, and applications dropped after 1990 when the government placed an excise tax on the reversion of money from over-funded plans. These developments cut the number of defined benefit participants by 25 percent. $^{7}$

In short, the shift in pension coverage started with the addition of a 401(k) feature to existing supplementary defined contribution plans, spread through the establishment of 401(k) plans at new companies in the late 1980s and again in the mid 1990s, and then gained prominence as defined benefit plans terminated.

\section{Reasons for the Shift}

The short answer is that 401(k) plans had enormous appeal to both employees and employers. A slightly longer explanation is that on the demand side the tastes of youth became more important in the labor market and a booming stock market made investing look easy and on the supply side the structure of industry changed and defined benefit plans became increasingly expensive. ${ }^{8}$

\footnotetext{
${ }^{6}$ Employers are not required to obtain an IRS determination letter to verify the qualified status of a newly initiated plan or prior to terminating a current plan. However, many do in order to provide assurance that the plan is qualified under IRC section 401(a) and the trust is exempt under section 501(a) (in the event of a new plan), and to reduce the risk of an IRS audit (in the event of plan termination). Although the issuance of determination letters is not an exact measure of new plan formation or termination, it provides useful insight to current plan and participant trends (see U.S. Internal Revenue Service, 2006).

${ }^{7}$ These numbers come from the Department of Labor's Form 5500. The PBGC (2003) also provides data on insured participants in single employer and multi-employer plans. The total number insured rose from 37.0 million in 1983 to 42.6 million in 1998. An increasing portion of these, however, were separated vested and retired participants. The number of active vested participants covered by the PBGC declined from 26.9 million in 1983 to 22.7 million in 1998.

${ }^{8}$ Evolving computer and communications technology made it a lot easier to administer a 401(k) plan. Letter from Sylvester Schieber, Watson Wyatt Worldwide (April 11, 2003).
} 
In the 1970s and 1980s, the baby boom and married women flooded into the labor market. ${ }^{9}$ For both these groups, the immediate reward of an account which they could control and take with them as they moved from job to job had much greater appeal than the delayed gratification of a defined benefit pension which would provide meaningful benefits only if they spent most of their career with the same employer. In the case of married women, this preference was quite rational given that they were likely to be in and out of the labor force as they attempted to combine career and family. The choice may or may not have been smart for young males. But the decline in labor unions weakened the voice of older workers and perhaps the support for a longer view towards work and retirement. ${ }^{10}$

If the stock market had faltered during the early years, young workers might have thought twice about the wisdom of managing their own retirement assets, but the debut of 401(k) plans coincided with the longest bull market in the country's history. Between 1982 and 2000 stock prices rose at annual rate of 16.9 percent compared to 8.7 percent between 1955 and 1981. With approximately half of 401(k) assets invested in equities, employees saw their accounts grow rapidly. Stock market performance and 401(k) accumulations became a regular subject of party conversation during the 1980s and 1990s. Most people became convinced that investing was easy and that they could do much better at managing their own money than stodgy sponsors of defined benefit plans. Thus, 401(k) plans were embraced by employees.

From the employers' perspective, 401(k) plans offered a form of pension that their workers appreciated. Moreover, for the employer these plans eliminated the risks involved in funding future retirement annuities. And the cost of a 401(k) plan was highly predictable, which became increasingly important during the 1980s as the economic environment became more competitive. These advantages of 401(k) plans would not have carried the day, however, if the need to encourage long service - a key factor in the design of traditional defined benefit plans - remained important.

\footnotetext{
${ }^{9}$ The labor force participation rate for married women rose from 40.5 percent in 1970 to 49.8 percent in 1980 and 58.4 percent in 1990 (U.S. Bureau of the Census, 2006, Table 585).

${ }^{10}$ By 1983, only 16.5 percent of private sector wage and salary workers were union members. That number has since declined to 7.9 percent in 2004 (U.S. Bureau of the Census, 2006, Table 647).
} 
But the nature of industry was changing dramatically. Employment was declining in large, unionized, manufacturing firms, which typically offered defined benefit plans, and was growing in "high-tech" firms and small, non-unionized companies in the services and trade sectors, which typically did not. ${ }^{11}$ Defined benefit plans are a sensible arrangement for large well-established firms; they are ill suited to service industries, where companies come and go. Several studies find that changes in industry composition, unionization, and firm size account for about half the decline in defined benefit coverage. $^{12}$

Even large organizations were reorganized in ways that reduced the value of longterm relationships between employer and employee. ${ }^{13}$ The new technologies arising in the area of information processing made the pyramid structure that had evolved for the mass production of standardized goods and services less useful. ${ }^{14}$ And new organizational arrangements were required to efficiently tap a more highly educated workforce. The response was to flatten the organization and break it into smaller units and teams that were responsible for particular projects or products. Moreover, the nature of the work required more in the way of generic human capital as opposed to firmspecific skills. To compensate outstanding employees, rewards needed to be based on performance rather than on long service. In such organizations, defined benefit plans were not just unnecessary, they were an actual hindrance. They forced management to spend money on adequate but unexceptional employees, since defined benefit plans rewarded older workers with firm-specific skills. They also made it expensive for managers to hire and difficult for managers fire mid-career employees. .

Just as employers had increasingly little to gain by offering pensions, the costs of such benefits also began to rise. Workers were living longer, making life-time annuities increasingly expensive. The reduction in inflation in the 1980s and 1990s raised the real

\footnotetext{
${ }^{11}$ Manufacturing employment declined from 61 percent of private sector employment in 1970, to 49 percent in 1980; to 35 percent in 1990; to 25 percent in 2005 (Economic Report of the President, 2006, Table B-46).

${ }^{12}$ See, for example, Schieber (1983), Andrews (1985), Gustman and Steinmeier (1992), and Ippolito (1995).

${ }^{13}$ Interestingly, the percent of the workforce employed by large organizations did not decline by as much as commonly thought. In 1972, 27.9 percent of the labor force worked for a firm with more than 10,000 employees. This percentage dropped to 24.2 percent in 1982 and 24.4 percent in 1992 (U.S. Bureau of the Census, 1994).

${ }^{14}$ The following argument was developed by Sass (1997).
} 
cost of un-indexed lifetime payments. In less-than-fully-funded plans, a dramatic increase in the number of retirees required large contributions relative to the size of the company. Finally, because employer plans held a significant portion of their assets in equities, large maturing plans produced significant volatility in company earnings and cash flow, with large losses and a spike in required contributions emerging in recessions, when sponsors were stressed.

The regulatory environment also caused existing small firms and new companies established in the 1980s and 1990s to opt for a 401(k). The Employee Retirement Income Security Act of 1974 (ERISA) imposed minimum standards for participation, vesting, and funding and required firms to insure pension benefits by paying premiums to the Pension Benefit Guarantee Corporation (PBGC). In addition to ERISA, during the 1980s Congress passed significant pension legislation every few years. ${ }^{15}$ Congress also repeatedly raised PBGC premiums and imposed an excise tax on employers who claim the excess assets of terminated defined benefit plans. The cumulative impact of the legislative changes increased the relative costs of defined benefit plans, particularly for small plans. ${ }^{16}$ A number of studies have identified regulatory costs as a factor in the decline of defined benefit plans. ${ }^{17}$

In short, the appeal of visible account balances and the sense of control provided by $401(\mathrm{k})$ plans, the response of the workplace to technological advances, the increased labor force participation of married women, the increased educational attainment of young workers, and regulatory costs all contributed to the dramatic shift in pension coverage from defined benefit to $401(\mathrm{k})$ plans. $^{18}$

\footnotetext{
${ }^{15}$ The Omnibus Reconciliation Act of 1987 reduced the full funding limits for defined benefit plans from 100 percent of projected plan liability to the lesser of that value or 150 percent of benefits accrued to date. Basing funding limits on benefits already accrued means that funding contributions no longer include any provision for anticipated pay increases (McGill et al, 1996). The funding restriction means that sponsors cannot get the full tax advantage that comes with the ability to prefund defined benefit plans and exposes the sponsor to higher costs in the future.

${ }^{16}$ The biggest increase in both absolute and relative costs of defined benefit versus defined contribution plans occurred in the late 1980s as plans adjusted to the Retirement Equity Act of 1984 and the Tax Reform Act of 1986 (Hustead, 1998).

${ }^{17}$ Kruse (1995) found that rising administrative costs contributed to the decline in defined benefit pension coverage over the period 1980-86.

${ }^{18}$ A considerably less important but reinforcing phenomenon was corporate raiders eager to get their hands on "excess" pension assets.
} 


\section{Shift in Pension Coverage and Tenure}

An additional factor often added to the list of reasons for the shift from defined benefit to $401(\mathrm{k})$ plans is the increased mobility of the labor force. Although press reports and casual commentators generally accept as established fact that jobs have become less stable in the United States, the research evidence is far from clear.

In the 1990s, research in the area of job stability was chaotic. Some researchers reported virtually no change in job stability over the 1970s and 1980s; others reported some declines. In 2000, the Russell Sage Foundation published a volume aimed at updating earlier results through the mid 1990s and trying to reconcile findings across data sets and across periods (Neumark 2000). But despite everyone's best efforts, the results were inconclusive. ${ }^{19}$ Almost every study in the volume found some increase in turnover or some decline in average tenure for some group, during some years between 1970 and 1995. But the editor cautions in his overview that it would be "premature to infer longterm trends towards declines in long-term employment relationships.”

As recently as 2005, studies produced very different results. Friedberg and Owyang (2005), using data from the Federal Reserve's Survey of Consumer Finances, conclude that current and remaining job tenure fell over the period 1983-2001. On the other hand, a recent paper (Stevens 2005) aptly titled "The More Things Change, the More They Stay the Same" comes to the opposite conclusion. Using three different data sets that follow people over an extended period of time, the author concludes that despite some ups and downs, the average tenure of workers in the longest job in their careers has remained virtually unchanged between 1969 and 2002 (21.9 to 21.4 years). ${ }^{20}$ Thus, it

\footnotetext{
${ }^{19}$ Jaeger and Stevens (2000), using the PSID and CPS tenure supplement, found that the share of workers with less than 18 months tenure increased in the early 1980s but not between 1983 and 1996 and the share with less than 10 years of tenure decreased slightly beginning in the late 1980s. They show that when the PSID and CPS are used in a comparable manner, they yield similar results, thus reconciling some earlier studies that showed declines in tenure in the 1970s and 1980s using the PSID (Marcotte 1996; Rose 1995) and none using the CPS tenure questions. Berhardt et al (2000) focused on young workers age 14-38, using the NLSYM and the NLSY, and found a substantial increase in two-year separation rates. Gottschalk and Moffitt (1999), looking at the whole population and using the SIPP and PSID, found no increase in oneyear separation rates. Neumark, Polsky, and Hansen (2000), using the CPS tenure and contingent worker supplement, concluded that four-year retention rates were unchanged in the early 1990s and 8-year retention rates fell for all workers; both rates declined for higher-tenure older workers.

${ }^{20}$ Specifically, the author uses data from the Retirement History Survey, which started in 1969, the National Longitudinal Study of Older Men, which started in 1966, and the Health and Retirement Study, which started in 1992. Using these data allows her to examine cohorts of men who are aged 58-62 years in each of the years 1969, 1975, 1980, 1992, 1998 and 2002.
} 
would be hard to argue on the evidence to date that a dramatic increase in mobility led to the spread of 401(k) plans.

On the other hand, it is difficult to believe that the dramatic shift towards 401(k) plans has not been associated - either as a cause or effect - with a change in employee-employer relationships. To identify possible patterns, this section uses the tenure supplements to the Current Population Survey and the SIPP to explore tenure trends. Whereas the earlier work on mobility was spurred by a wave of downsizing and press reports that "the notion of lifetime employment has come to seem as dated as soda jerks, or tail fins” (New York Times, March 8, 1996), this analysis focuses on the possible interaction between pensions and tenure. ${ }^{21}$ Two possibilities exist. First, a significant increase in mobility occurred throughout the workforce, making 401(k)s a much more attractive vehicle - the chicken, then the egg. Alternatively, as much of the earlier literature suggests virtually nothing happened in the 1970s and 1980s and mobility increased only after the spread of 401(k) plans - the egg, then the chicken. In this case, changes in mobility would be expected primarily among older workers, who would have lost significant pension benefits by shifting jobs under the traditional defined benefit plans.

\section{The CPS Data}

The CPS tenure supplements are available for 1973, 1978, 1981, 1983, 1987, 1991, 1996, 1998, 2000, 2002, and 2004. ${ }^{22}$ The question changes slightly over the period. In 1973, 1978, and 1981, the question refers to time working at the present job or business, while for 1983 and later the question refers to working "continuously" for the present employer. To the extent to which respondents in the earlier surveys experienced temporary separations, their responses will make them look like they have more tenure than they actually had. If the purpose of this analysis were to demonstrate declining tenure in the 1980s, such a bias might be a problem. But that is not the goal, and other

\footnotetext{
${ }^{21}$ This quote was reported in Neumark, Polsky, and Hansen (2000).

${ }^{22}$ All data are from the Workplace Topics I (January/February) supplements, although the 1973 tenure data are from the displaced worker supplement.
} 
researchers make no adjustment. Thus, the raw median tenure data for employed males and females are presented in Figure $5 .^{23}$

The results are striking in two respects. First, before 1990 the median years of tenure for both males and females is virtually flat for every age group. (As discussed below, the data for males are probably more meaningful than that for females.) These data confirm much of the earlier work on mobility that showed very little change during the 1970s and 1980s. Second, beginning in 1990, after a decade of 401(k) plans, the median tenure for men at older ages starts to decline. If the shift in pension coverage were to have an effect, this is where one would expect to find it. Pension accumulations are very small at younger ages, and - even for the average worker aged 35-54 - the pension loss associated with switching jobs is approximately half a year's earnings. ${ }^{24}$ The fact that the decline in tenure occurs at older ages suggests that the shift in pension coverage had an effect. ${ }^{25}$

The tenure data for women are a little harder to interpret. Two factors are at play - particularly before 1990. On the one hand, as noted above, the labor force participation rate for married women rose from 40.5 percent in 1970 to 49.8 percent in 1980 and 58.4 percent in $1990 .^{26}$ All else equal, this influx would be expected to reduce tenure. On the other hand, women who had previously worked were becoming more serious about their careers, which would be expected to increase median tenure. Before 1990, these two forces appear to have balanced out. The question is why median tenure for older women did not decline after 1990 when the tenure for men started to fall. Several factors may be

\footnotetext{
${ }^{23}$ Median tenure is calculated in a manner similar to Farber (1995). The sample includes individuals ages 16 and older, currently working or with a job but not currently at work, nonagricultural workers, and excluding unincorporated self-employed.

${ }^{24}$ See Allen, Clark, and McDermed (1988). Gustman and Steinmeier (1993) emphasize how small pension wealth is early in workers' careers and argue that the main impact of defined benefit pensions would be to deter mobility for long-tenured workers.

${ }^{25}$ Aaronson and Coronado's (2005) conclusions appear to contradict the notion that 401(k) plans came first and then mobility. The authors look at the change in pension coverage using data drawn from the May supplement to the 1979 CPS and the pension supplement administered in 1998 to the 1996 panel of the SIPP. They find that industries where the average tenure was less than 5 years were more likely to experience a decline in the proportion of workers covered by a defined benefit plan and an increase in workers covered by a defined contribution plan. These results probably say less about causation, however, than about the mechanics of plan adoption. The very fact that 401(k)s were adopted by new companies with young workers would yield a positive coefficient in the defined contribution equation and that defined benefit plans were most prevalent in established industries with long-tenured workers would yield a negative coefficient in the defined contribution equation.

${ }^{26}$ U.S. Bureau of the Census (2006) Table 585.
} 
at play. First, a somewhat smaller portion of older women than men were covered by a defined benefit plan and therefore did not experience the relief in terms of mobility offered by the shift to $401(\mathrm{k})$ plans. ${ }^{27}$ Second, the labor force participation rate of married women stabilized about that time, suggesting that an influx of new workers was no longer exerting downward pressure on tenure. On the other hand, women's increased commitment and career success may have extended tenure. This increasing commitment to career may have offset any increase in mobility enabled by the shift from defined benefit to 401(k) plans. At a minimum, it would be hard to argue that declining tenure among women led to the shift to 401(k) plans.

Finally, the CPS tenure data can be used to look at the tenure of older workers in a slightly different way. Specifically, for each survey it is possible to identify those working full time at age 55, 60 etc who are still with the same employer they worked for at age 50. Under a defined benefit plan, workers would suffer a substantial loss of benefits by moving in their fifties, whereas no such loss occurs under a 401(k) plan. Mechanically, this exercise involves simply asking, say, the 55-year-old full-time worker how long he has been with his current employer. If the response is five years or more, the worker is classified as working with his age-50 employer. Those working with the same employer are then divided by total workers to get the proportion of the workforce with what used to be thought of as the typical pattern of employment

The results, which are shown in Figure 6 separately for men and women, mirror the tenure information presented above. In each of the early surveys, at age 60, approximately 60 percent of male workers and 40 percent of female workers were working for the same employer as they were when they were age 50. After the early 1990s, the picture changes noticeably for men; at age 60 less than 45 percent of male workers are working full time with their age-50 employer. As in the data on median tenure, the picture for women remains unchanged. In short, male workers in their 50s appear to be shifting jobs more in a 401(k) world than they did when covered by defined benefit plans.

\footnotetext{
${ }^{27}$ Moreover many women with defined benefit coverage are public sector teachers who traditionally change jobs infrequently.
} 


\section{The SIPP Data}

In order to confirm the results from the CPS tenure supplement, this section reports tenure data from the Survey of Income and Program Participation (SIPP). Since 1984, the U.S. Census Bureau of Demographic Research has interviewed panels of individuals, asking them a series of core questions every four months for about two and a half years. Prior to the 1996 panel, an individual's tenure could be derived from the “Employment History” module, which included the question "When did you start working for (employer's name)?” Data for this module were collected in either the first or second wave for the 1986-1993 panels, although the data from the 1989 panel were not released. In the 1996 and 2001 panels, the identical question was asked in each wave. The SIPP question on tenure is unique because it requires respondents to provide the year and month in which they began employment, allowing tenure to be calculated to the fraction of a year.

The tenure data for both males and females is reported in Figure 7. Due to the limitations of the SIPP, data are available only since 1986. But for the period for which the CPS and SIPP data overlap, the story is virtually identical. Beginning around 1990, the median tenure for older male workers declines markedly. For males at younger ages and for females, median tenure remains virtually unchanged.

\section{Retention Rates}

The weakness of median tenure data is that they are susceptible to changes in arrival rates - that is, the number of workers beginning new jobs. For example, the surge of married women and baby boomers onto the job market in the 1970s and 1980s would have been expected to reduce median tenure. The fact that median tenure showed no decline suggests that it may even have risen in the absence of the new workers. Therefore, for the story presented in this paper - namely, no reduction in tenure before the early 1990s - the potential bias due to new arrivals is not a problem. On the other hand, the contention that tenure declined sharply after the early 1990s could be affected by new arrivals. In this case, the new workers would be the influx of immigrants who arrived in the 1980s and 1990s (see Figure 8). 
A way around the problem of new arrivals is to look at retention rates. ${ }^{28} \mathrm{~A}$ retention rate, $R_{x c}(t)$, is the probability that a worker will have an additional t years of tenure $t$ years in the future. Formally, the t-year retention rate for workers with c years of tenure and characteristics $\mathrm{x}$ is the ratio of the number of workers with $\mathrm{c}+\mathrm{t}$ years of tenure and characteristics $\mathrm{x}$ in the supplement t years in the future, $N_{x, c+t}{ }^{0+t}$, to the number of workers with c years of tenure in the current tenure supplement, $N_{x c}{ }^{0}$.

$$
R_{x c}{ }^{0}(t)=\frac{N_{x, c+t}{ }^{0+t}}{N_{x c}{ }^{0}}
$$

An example will help clarify the calculation. In 1983, of workers aged 35-39, say, 100 had tenure of between 5 and 10 years; in 1987, of workers aged 39-43 - that is, the same cohort of workers - 75 had tenure of between 9 and 14 years. Thus, the four-year retention rate for this group is 75 percent.

Neumark, Polsky, and Hansen (2000) present retention rates through 1995 based on the CPS tenure supplements and the 1995 February Contingent Work Supplement. They made a number of adjustments to ensure that the surveys were as comparable as possible across time. ${ }^{29}$ They adjusted for differences in non-response rates in the various surveys. They meticulously checked to make sure the 1995 data were consistent with the earlier tenure supplements since the 1995 data came from a different survey and the question regarding length of time with current employer did not include the word “continuous." And they adjusted for "rounding” and "heaping." Rounding arises in the early surveys because answers for less than a year are reported in months but for more than a year are reported in years. Those workers with a year and a half or more would tend to round up to two years and be classified as having "two to three years of tenure," which probably explains why this group is larger than the group reporting "one to two

\footnotetext{
${ }^{28}$ The notion of using retention rates dates back to Hall (1982). He estimated expected job tenure from a single (1978) tenure supplement. This approach, however, requires the strong assumptions that the employment survival function is stable over time and that the overall arrival rate is constant (Ureta 1992). Neither assumption applies to the analysis in this paper, since women, baby boomers, and immigrants swelled the labor force and the basic hypothesis is that pensions changed the pattern of employment. Therefore, the more modest approach of estimating retention rates used by Diebold, Neumark, and Polsky (1997) and Neumark, Polsky, and Hansen (2000) by linking together a sequence of tenure supplements is the more reasonable approach.

${ }^{29}$ Although Diebold, Neumark, and Polsky (1997) adjusted for the business cycle, this adjustment had little effect on their results; Neumark, Polsky, and Hansen (2000) made no such adjustment.
} 
years." Heaping is the tendency for workers to report their tenure in multiples of 5 years - that is, $5,10,15$ etc.

Appendix Table A1 reports retention rates for the entire population and for older workers by initial tenure. The 1983-1987, 1987-1991, and 1991-1995 rates duplicate the Neumark, Polsky, and Hansen calculations; the 1996-2000 and 2000-2004 retention rates are from the latest surveys. No adjustment is made for rounding because the cause of the problem disappears after 1991 (since respondents are not constrained to answer in full years and the focus is not on short tenure) or for heaping because the adjusted and unadjusted numbers yield essentially the same picture.

The reason for looking at the retention rates is to check whether the decline in median tenure reported in the previous section reflects a real change in labor market activity of older workers or simply the influx of immigrants. Table 2 therefore presents retention rates for male workers aged 45-54 and 55-64. It also includes the change in retention rates over time and tests whether the differences are statistically significant. ${ }^{30}$ The results show that the retention rates for older male workers were significantly lower in 1996-2000 than in 1983-1987. ${ }^{31}$ Therefore, the retention rates and median tenure data tell the same story - older workers became more mobile in the 1990s as coverage under defined benefit plans declined.

\footnotetext{
${ }^{30}$ Following Neumark, Polsky, and Hansen (2000), the retention rate $\mathrm{R}_{\mathrm{xc}}{ }^{0} \mathrm{t}$ ) denotes the t-year retention rate of individuals with demographic characteristics $\mathrm{x}$ and initial tenure of $\mathrm{c}$ for the base year 0 . For testing the significance of a change in the t-year retention rates for base years that are $n$ years apart, we calculate the standard error as the square root of the sum of the variances of the estimated retention rates.$$
s=\sqrt{\operatorname{var}\left(\hat{R}_{x c}^{0}(t)\right)+\operatorname{var}\left(\hat{R}_{x c}^{0+n}(t)\right)}
$$

where$$
\operatorname{var}\left(\hat{R}_{x c}{ }^{0}(t)\right)=\frac{\hat{R}_{x c}{ }^{0}(t) \times\left(1-\hat{p}_{x, c+t}{ }^{0+t}\right)}{N_{x c}{ }^{0}}
$$

where $\hat{p}_{x, c+t}{ }^{0+t}$ is the estimated proportion of the population in time $0+\mathrm{t}$ that have $\mathrm{c}+\mathrm{t}$ years of tenure, calculated as the estimated population retention rate times the proportion of individuals with characteristics $\mathrm{x}$ in the sample. Thus in the cases where we compare retention rates for all individuals, we estimate this variance as the estimated retention rate times (1-estimated retention rate) divided by the number of individuals in the base year with tenure of $c$.

${ }^{31}$ As shown in TableA1, retention rates from the 1996-2000 to the 2000-2004 periods actually increased for all age groups. This pattern is hard to explain, but it does mirror the pattern in other CPS data, such as the decrease in job separation rates in 2004 compared to earlier years.
} 


\section{Relationship between Tenure and Pension Type}

The final exercise is to use 1998 and 2003 SIPP data to estimate the relationship between pension coverage and tenure for older workers (aged 45-64). The analysis proceeds in three steps. The first is to regress each worker's years of tenure against a year dummy, which is set equal to 1 for 2003. The second step is to introduce a host of control variables that might explain the decline in tenure between 1998 and 2003, such as age, gender, education, nature of the firm, nature of the job, union coverage etc. This step also requires a pension coverage variable because the SIPP recorded an increase in pension coverage overall during this period. As shown in Table 3, of those with pension coverage the percent relying only on a defined contribution plan increased from 43 percent to 58 percent over the five years. ${ }^{32}$ The third step is to re-estimate the second equation replacing the pension coverage dummy with a variable for coverage under a defined benefit plan only, a defined contribution plan only, or both.

The focus of the analysis is not only the coefficients on the pension variables but also the size and significance of the year dummy. The hypothesis is that the decline in tenure is associated with a continued shift from defined benefit to defined contribution plans, so that once this information is introduced into the equation the year dummy no longer has an explanatory power.

The results are reported in Table $4 .{ }^{33}$ The first equation shows that the movement from 1998 to 2003 reduced average tenure by .67 of a year, and the coefficient of the year dummy is statistically significant. The second equation introduces the control variables, virtually all have the expected sign and are statistically significant. ${ }^{34}$ It also includes a

\footnotetext{
${ }^{32}$ People were classified by type of pension coverage based on three questions. 1) If a person said their benefits were determined by a formula involving years of service or salary they were said to have a DB plan, while if they said it was an individual account, they were said to be participating in a DC plan. People participating in a cash balance plans were labeled as participating in a DB plan. 2) People who had different primary or secondary types of plans, or, or who participated in a supplementary tax-deferred plan were labeled as Both DB\&DC. 3) The SIPP asks a series of detailed follow-up questions about the primary plan. People who said that they had a defined benefit plan but also said that they contributed to the plan, that these contributions were taxed deferred, that their benefits were dependent on their contributions, and that they could choose how much was invested or take out loans from their account were relabeled as defined contribution participants (see Copeland, 2002).

${ }^{33}$ To ensure that the model was stable from 1998 to 2003, a separate equation was estimated that included interactions for all variables. These calculations, which are not shown here, indicate that the model did not structurally change from 1998 to 2003.

${ }^{34}$ The exceptions are being non-white and having a college education, neither of which have a statistically significant effect on the tenure of older workers.
} 
variable for pension participation, which increased in the SIPP between 1998 and 2003 and all else equal would have been expected to increase tenure. Including most of the variables that could have had an impact on tenure reduces the impact of the year dummy from .67 to .37 , but the coefficient is still statistically significant.

The third equation replaces pension participation with variables for coverage under a defined benefit plan only, a defined contribution plan only, or both a defined benefit and a defined contribution plan. The coefficients on the pension variables are both large and statistically significant. Coverage under a defined benefit plan only increases tenure by 4.0 years compared to no pension coverage; under a defined benefit and defined contribution plan by 5.8 years; and under a defined contribution plan only by 2.7 years. ${ }^{35}$ Thus, for those with pension coverage the shift in coverage from a defined benefit plan to a defined contribution plan implies a reduction in average tenure of 1.3 to 3.1 years. Moreover, once the variables for pension type are included, the coefficient of the year dummy is no longer statistically significant.

The clear implication from the three equations is that the reduction in tenure between 1998 and 2003 and the shift in coverage from defined benefit to defined contribution plans are related. Unfortunately, it is impossible with these equations to say that the shift in pension coverage caused the decline in tenure, but the rest of the evidence presented in this paper suggests that may be the case.

\section{Conclusion}

The stimulus for the preceding analysis was the apparent gulf between commentators attributing the rise of $401(\mathrm{k})$ plans to a dramatic increase in labor mobility and the inability of labor economists to find any systematic change in labor market behavior during the 1970s and 1980s. At the same time, it was difficult to believe that the truly remarkable shift in the nature of pension coverage had virtually no impact on worker tenure.

Two conclusions emerge from the preceding analysis. First, the labor economists who study mobility in the 1970s and 1980s appear to be correct. Even though the

\footnotetext{
35 These coefficients are very similar to those obtained by Friedberg and Owyang (2005) using the 1983, 1989, 1992, 1995, 1998 and 2001 Surveys of Consumer Finances.
} 
structure of personnel and production systems was changing in the late 1970s and early 1980s, tenure and retention rates were steady during this period. Commentators should delete increased mobility from their list of reasons for the shift to 401(k) plans. Second, after the widespread adoption of 401(k) plans, mobility and tenure patterns changed. And the change occurred among the group that would have been most constrained from moving under a defined benefit regime - namely, older workers with long tenure. It is impossible to prove that the shift in coverage caused the increased mobility, but it appears that the egg came first then the chicken. 


\section{References}

Aaronson, Stephanie and Julia Coronado. 2005. “Are Firms or Workers Behind the Shift Away from DB Pension Plans?” Finance and Economics Discussion Series No. 2005-17, Federal Reserve Board of Governors, April 2005.

Allen, Steven, Robert Clark, and Ann McDermed. 1993. "Pensions, Bonding, and Lifetime Jobs.” Journal of Human Resources 28(3): 463-81.

Bernhardt, Annette, et al. 2000. "Trends in Job Instability and Wages for Young Adult Men.” In On the Job: Is Long-Term Employment a Thing of the Past?, edited by David Neumark. New York: Russell Sage Foundation.

Buessing, Marric and Mauricio Soto. 2006. “The State of Private Pensions: Current 5500 Data.” Issue Brief 44. Chestnut Hill, MA: Center for Retirement Research at Boston College.

Clark, Robert L. and Sylvester Schieber. 2002. "Taking the Subsidy out of Early Retirement: Converting to Hybrid Pensions.” In Innovations in Managing Financial Risk in Retirement. Edited by Olivia Mitchell, Zvi Bodie, Brent Hammond, and Stephen Zeldes. Philadelphia, PA: University of Pennsylvania Press.

Diebold, Francis X., David Neumark, and Daniel Polsky. 1997. "Job Stability in the United States.” Journal of Labor Economics, April 1997, 15(2): 206-233.

Farber, Henry S.1995. “Are Lifetime Jobs Disappearing? Job Duration in the United States: 1973-1993.” Working Paper 5014. Princeton, NJ: National Bureau of Economic Research.

Freidberg, Leora and Michael T. Owyang. 2005. "Explaining the Evolution of Pension Structure and Job Tenure.” Working Paper. St. Louis, MO: Federal Reserve Bank of St. Louis.

Gottschalk, P., and R. Moffitt. 1999. "Changes in Job Instability and Insecurity Using Monthly Survey Data.” Journal of Labor Economics 17(4): S91-S26.

Gustman, Alan L., Olivia S. Mitchell, and Thomas Steinmeir. 1994. "The Role of Pensions in the Labor Market: A Survey of the Literature.” Industrial and Labor Relations Review 47(3): 417-438.

Gustman, Alan L. and Thomas L. Steinmeier. 1992. "The Stampede Toward Defined Contribution Pension Plan: Fact or Fiction?” Industrial Relations 31(2): 361-69.

Gustman, Alan and Thomas Steinmeier. 1993. "Pension Portability and Labor Mobility.” Journal of Public Economics 50: 299-323. 
Hall, Robert. 1982. "The Importance of Lifetime Jobs in the U.S. Economy.” American Economic Review 72: 716-24.

Hustead, Edwin C. 1998. "Trends in Retirement Income Plan Administrative Expenses.” In Living with Defined Contribution Plans: Remaking Responsibility, edited by Olivia S. Mitchell and Sylvester J. Scheiber, 166-77. Philadelphia, PA: University of Pennsylvania Press for the Pension Research Council.

Ippolito, Richard A. 1995. "Toward Explaining the Growth of Defined Contribution Plans.” Industrial Relations. 34(1): 1-20.

, 1999. "The New Pension Economics: Defined Contribution Plans and Sorting.” Paper prepared for EBRI policy forum on the next twenty-five years of ERISA.

Jaeger, David A., and Stevens, Ann Huff. 2000. "Is Job Stability in the United States Falling? Reconciling Trends in the Current Population Survey and the Panel Study of Income Dynamics.” In On the Job: Is Long-Term Employment a Thing of the Past?, edited by David Neumark. New York: Russell Sage Foundation.

Kruse, Douglas L. 1995. "Pension Substitution in the 1980's: Why the Shift toward Defined Contribution Plans?” Industrial Relations 34(2): 218-41.

Marcotte, David E. 1996. "Has Job Stability Declined?: Evidence from the Panel Study of Income Dynamics.” Unpublished paper. DeKalb, IL: Center for Governmental Studies at Northern Illinois University.

Marcotte, David E. 1995. "Declining Job Stability: What We Know and What It Means." Journal of Policy Analysis and Management 14(4): 590-98.

McGill, Dan M., Kyle N. Brown, John J. Haley and Sylvester J. Schieber. 1996. Fundamentals of Private Pensions, Seventh Edition. Philadelphia, PA: University of Pennsylvania Press.

Munnell, Alicia H. and Annika Sundén. 2004. Coming Up Short: The Challenge of 401(k) Plans. Washington, DC: Brookings Institution Press.

Munnell, Alicia H., Francesca Golub-Sass, Mauricio Soto and Francis Vitagliano. 2006. "Why Are Healthy Employers Freezing Their Pensions?” Issue in Brief 44. Chestnut Hill, MA: Center for Retirement Research at Boston College.

Neumark, David. 2000. "Change in Job Stability and Job Security: A Collective Effect to Untangle, Reconcile, and Interpret the Evidence.” In On the Job: Is Long-Term Employment a Thing of the Past, edited by David Neumark. New York: Russell Sage Foundation. 
Neumark, David, Daniel Polsky, and Daniel Hansen,.2000.”.Has Job Stability Declined Yet? New Evidence for the 1990s.” In On the Job: Is Long-Term Employment a Thing of the Past?, edited by David Neumark. New York: Russell Sage Foundation.

Papke, Leslie, Mitchell Petersen, and James Poterba. 1996 “Do 401k Plans Replace Other Employer Provided Pension?” In Advances in the Economics of Aging, edited by David A. Wise, 219-40. University of Chicago Press.

Pension Benefit Guaranty Corporation, Pension Insurance Data Book (2003). Washington, DC: Government Printing Office.

Rose, Stephen. 1995. "Declining Job Security and the Professionalization of Opportunity.” Research report 95-4. Washington, DC: National Commission for Employment Policy.

Sass, Steven A. 1997. The Promise of Private Pensions. Cambridge, MA: Harvard University Press.

Stevens, Ann Huff. 2005. “The More Things Change: The More They Stay the Same: Trends in Long-Term Employment in the United States, 1969-2002.” Working Paper 11878. Princeton, NJ: National Bureau of Economic Research

Ureta, Manuelita. 1992. "The Importance of Lifetime Jobs in the U.S. Economy, Revisited.” American Economic Review 82:1(March): 322-335.

U.S. Bureau of the Census. 1994. General Report on Industrial Organization 1972-1992. Washington, DC: U.S. Government Printing Office.

U.S. Department of Labor. 2001-2002. Private Pension Plan Bulletin: Abstract of 1998 Form 5500 Annual Reports. Washington, DC: U.S. Government Printing Office.

U.S. Department of Labor. 2006. Economic Report of the President. U.S. G.P.O. Washington, DC.

U.S. Internal Revenue Service. 1988-2002. IRS Data Book. Publication 55b. Washington, DC: Government Printing Office.

U.S. Internal Revenue Service. 2006. “EP Determination Letter Resource Guide - Do I Need to File for a Determination Letter for my Retirement Plan" http://www.irs.gov/retirement/article/0,,id=128038,00.html Washington, DC: Government Printing Office. 
Warshawsky, Mark J. 1995. "Determinants of Pension Plan Formations and Terminations.” Benefits Quarterly. (Fourth Quarter): 71-80. 
Table 1. Percent of 401(k) Participants in 1995 by Date of Plan Establishment

\begin{tabular}{|l|c|}
\hline Date plan established & Percent of participants \\
\hline Pre-1980 & 30.0 \\
\hline $1980-1984$ & 17.6 \\
\hline $1985-1989$ & 27.7 \\
\hline $1990-1994$ & 19.6 \\
\hline 1995 & 4.8 \\
\hline Date not specified & 0.2 \\
\hline
\end{tabular}

Source: U.S. Department of Labor. 2001-2002. Private Pension Plan Bulletin: Abstract of 1998 Form 5500 Annual Reports. Washington, DC. 
Table 2. Estimated Four-Year Retention Rates for Older Male Workers using CPS Data, by Tenure Group

\begin{tabular}{|c|c|c|}
\hline \multirow{2}{*}{$\begin{array}{l}\text { Time span and } \\
\text { initial tenure group }\end{array}$} & \multicolumn{2}{|c|}{ Retention rate } \\
\hline & Aged 45-54 & Aged 55-64 \\
\hline \multicolumn{3}{|l|}{ 1983-1987 } \\
\hline 0 to $<2$ & .628 & .485 \\
\hline 2 to $<9$ & .666 & .624 \\
\hline 9 to $<15$ & .795 & .481 \\
\hline $15+$ & .797 & .475 \\
\hline Total & .744 & .509 \\
\hline & & \\
\hline \multicolumn{3}{|l|}{ 1996-2000 } \\
\hline 0 to $<2$ & .516 & .426 \\
\hline 2 to $<9$ & .609 & .486 \\
\hline 9 to $<15$ & .679 & .590 \\
\hline $15+$ & .685 & .451 \\
\hline Total & .635 & .474 \\
\hline & \multicolumn{2}{|c|}{$1983-1987$ to $1996-2000$} \\
\hline 0 to $<2$ & $-.113^{*}$ & -.059 \\
\hline 2 to $<9$ & -.057 & -.138* \\
\hline 9 to $<15$ & $-.116^{*}$ & $.109 *$ \\
\hline $15+$ & $-.112 *$ & -.024 \\
\hline Total & $-.109 *$ & -.034 \\
\hline
\end{tabular}

Source: Authors' calculations.

* Denotes the difference in 4-year retention rates is statistically significant at the 5-percent level. 
Table 3. Descriptive Data from the SIPP for Workers Aged 45-64, 1998 and 2003

\begin{tabular}{|l|r|r|}
\hline Characteristic & \multicolumn{1}{|c|}{1998} & \multicolumn{2}{c|}{2003} \\
\hline Pension participation & 60.7 & 62.5 \\
\hline Participation by type: & & \\
\hline DB only & 35.2 & 25.6 \\
\hline DC only & 43.2 & 57.8 \\
\hline Both & 21.6 & 16.7 \\
\hline Median tenure & 9.8 & 7.8 \\
\hline With pension & 12.8 & 12.6 \\
\hline Without pension & 4.9 & 3.9 \\
\hline Mean tenure & 12.1 & 11.4 \\
\hline With pension & 14.5 & 13.8 \\
\hline Without pension & 8.4 & 7.5 \\
\hline
\end{tabular}

Source: Authors' calculations 
Table 4. OLS Results for Tenure, SIPP 1998 and 2003

\begin{tabular}{|c|c|c|c|c|c|c|}
\hline \multirow[b]{2}{*}{ Variable } & \multicolumn{2}{|c|}{ (1) } & \multicolumn{2}{|c|}{ (2) } & \multicolumn{2}{|c|}{ (3) } \\
\hline & Coefficient & (t-stat) & Coefficient & (t-stat) & Coefficient & (t-stat) \\
\hline Year & -.665 & $(-4.53)$ & -.361 & $(-2.25)$ & -.241 & $(-1.51)$ \\
\hline $\begin{array}{l}\text { Pension } \\
\text { participation }\end{array}$ & & & 3.588 & (22.65) & & \\
\hline DB only & & & & & 4.048 & (19.75) \\
\hline DC only & & & & & 2.702 & (15.31) \\
\hline Both DB \& DC & & & & & 5.813 & (24.37) \\
\hline Age 50-54 & & & 1.538 & (9.47) & 1.514 & (9.37) \\
\hline Age 55-59 & & & 2.517 & (13.72) & 2.532 & (13.87) \\
\hline Age 60-64 & & & 3.876 & $(17.02)$ & 3.910 & $(17.25)$ \\
\hline Female & & & -.728 & $(-5.05)$ & -.724 & $(-5.05)$ \\
\hline Married & & & .875 & (5.85) & .882 & (5.94) \\
\hline Nonwhite & & & -.077 & $(-0.47)$ & .016 & $(0.10)$ \\
\hline College & & & -.694 & $(-4.32)$ & -0.717 & $(-4.48)$ \\
\hline Metro & & & -.372 & $(-2.24)$ & -.408 & $(-2.47)$ \\
\hline $\begin{array}{l}\text { Public sector } \\
\text { worker }\end{array}$ & & & 1.936 & $(10.74)$ & 1.788 & (9.88) \\
\hline $\begin{array}{l}\text { Private sector -- } \\
\text { goods }\end{array}$ & & & 1.882 & $(10.84)$ & 1.848 & (10.69) \\
\hline Large firm & & & .775 & (4.81) & .649 & (4.04) \\
\hline Union & & & 3.450 & (19.34) & 3.227 & (18.03) \\
\hline High paid & & & 2.522 & $(15.41)$ & 2.518 & $(15.46)$ \\
\hline Earnings & & & .0003 & $(13.40)$ & .0003 & $(12.80)$ \\
\hline $\begin{array}{l}\text { Unemployment } \\
\text { rate in state }\end{array}$ & & & -.348 & $(-4.73)$ & -.348 & $(-4.75)$ \\
\hline Constant & 12.077 & (116.66) & 5.418 & (12.96) & 5.509 & (13.24) \\
\hline $\mathrm{R}^{2}:$ & .00 & & .17 & & .18 & \\
\hline Observations & 18,8 & & 18,8 & & 18,8 & \\
\hline
\end{tabular}

Age dummies take on value of 1 if an individual lies within the specified age category. Female, Married, Nonwhite, College, and Metro are dummy variables set equal to 1 when the person has the characteristic or lives in a metro area. The work-related variables relate to the person's primary employment and take on a value of 1 if a person works in the public sector, works in the private goods sector, works for a firm with over 100 employees, is a member of a union, has some or all his health insurance paid for by the employer, and participates in a pension plan, respectively. "Earnings” is a continuous variable representing a person's monthly income from his primary job. The state unemployment rate comes from the Bureau of Labor Statistics. The 'year' dummy takes on a value of 1 for 2003. 
Figure 1. Accrued Pension Benefits in a Traditional Defined Benefit and 401(k) Plan

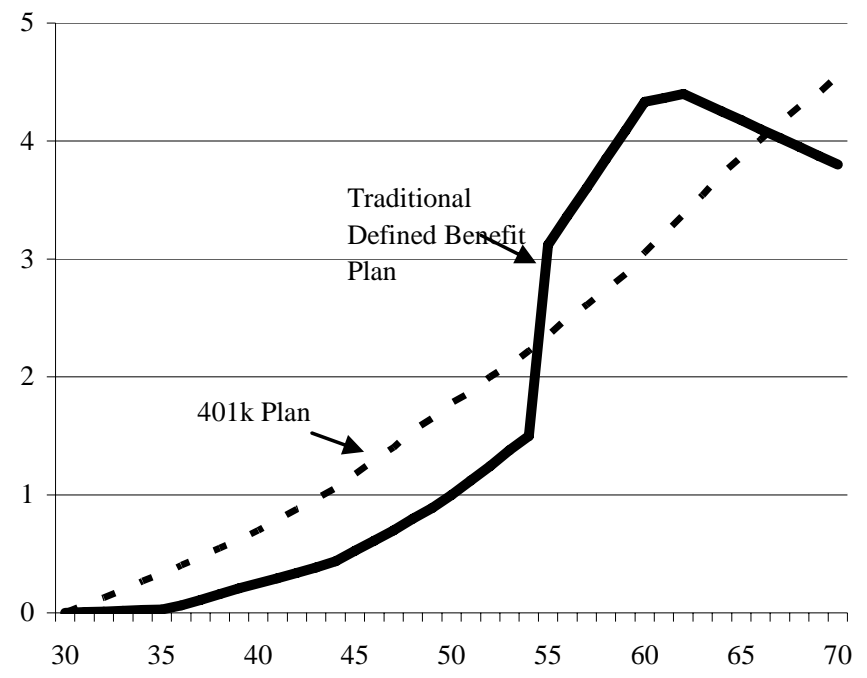

Source: Clark and Schieber (2002). 
Figure 2. The Impact of Mobility on Defined Benefit Replacement Rates

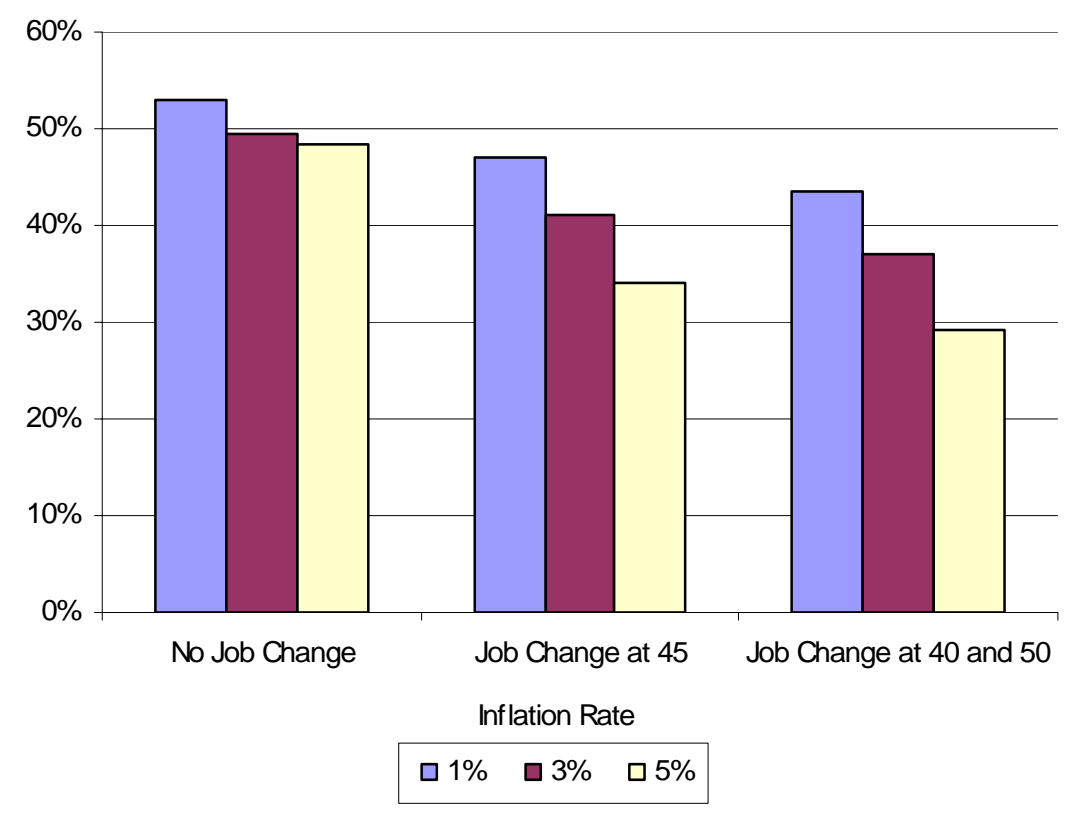

Source: Munnell and Sundén (2004).

Note: Calculations assume 4.1 percent nominal wage growth, with inflation at 3 percent and real wage growth at 1.1 percent. The age-earnings profile is based on career earnings profiles for males and females born between 1926 and 1965. In this profile, earnings reach a peak at age 47. After adding the economywide factors, real wages peak at age 51 and nominal wages at age 61 . The salary at age 50 equals $\$ 44,000$ - the median wage for a 50-year old covered by a pension plan in the 2001 Survey of Consumer Finances. This results in a salary of $\$ 17,000$ at age 30 , when the workers in the simulation begin to participate in a plan; and an ending salary of $\$ 52,650$ at age 62 . The contribution rate for the $401(\mathrm{k})$ is 9 percent a year, with a 7.6 percent nominal rate of return on assets. Defined-benefit plan amounts are based on 1.5 percent of the average of the last five salaries for each year of service, with a 5-percent discount for each year of benefit receipt before age 62 .

Source: Munnell and Sundén (2004). 
Figure 3. Private Sector Workers with Pension Coverage, by Pension Type, 1980, 1992, and 2004.

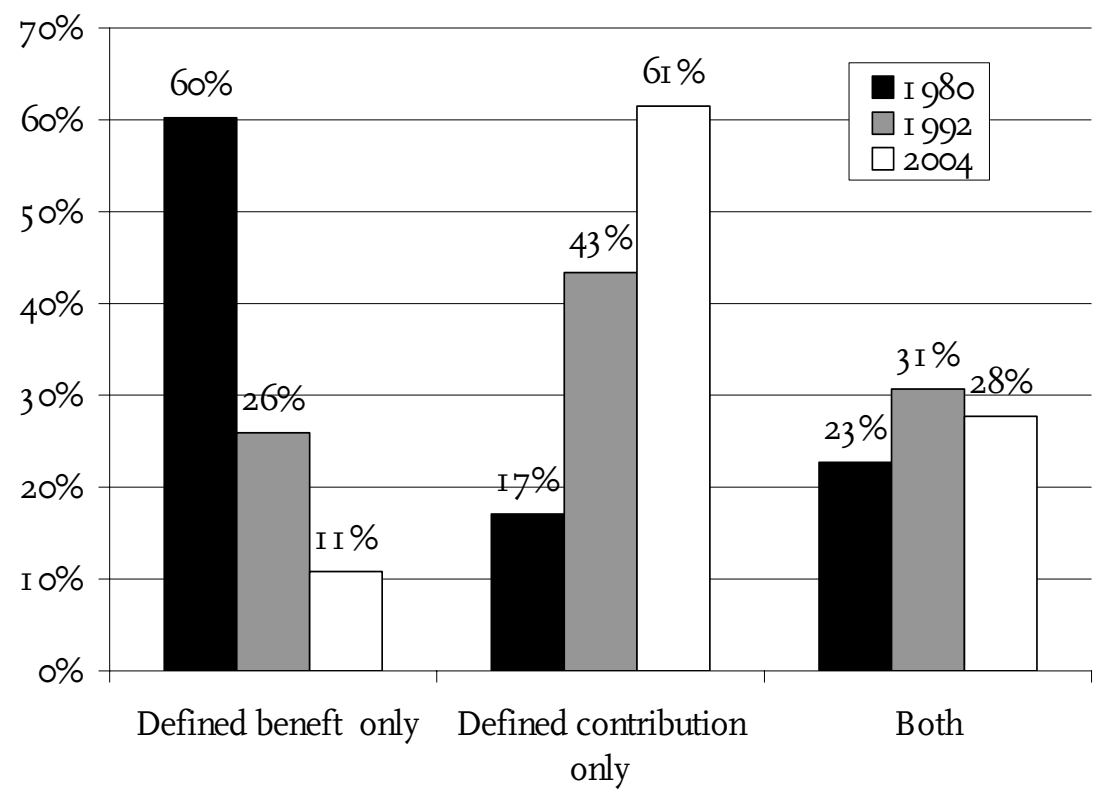

Note: Although these calculations adjust for double-counting, some overestimation of coverage may still remain.

Sources: U.S. Department of Labor (2004) and authors' calculations from U.S. Department of Labor (2006). 
Figure 4. Net Change in Defined Benefit and Defined Contribution Plans Based on IRS Applications, 1960-2005

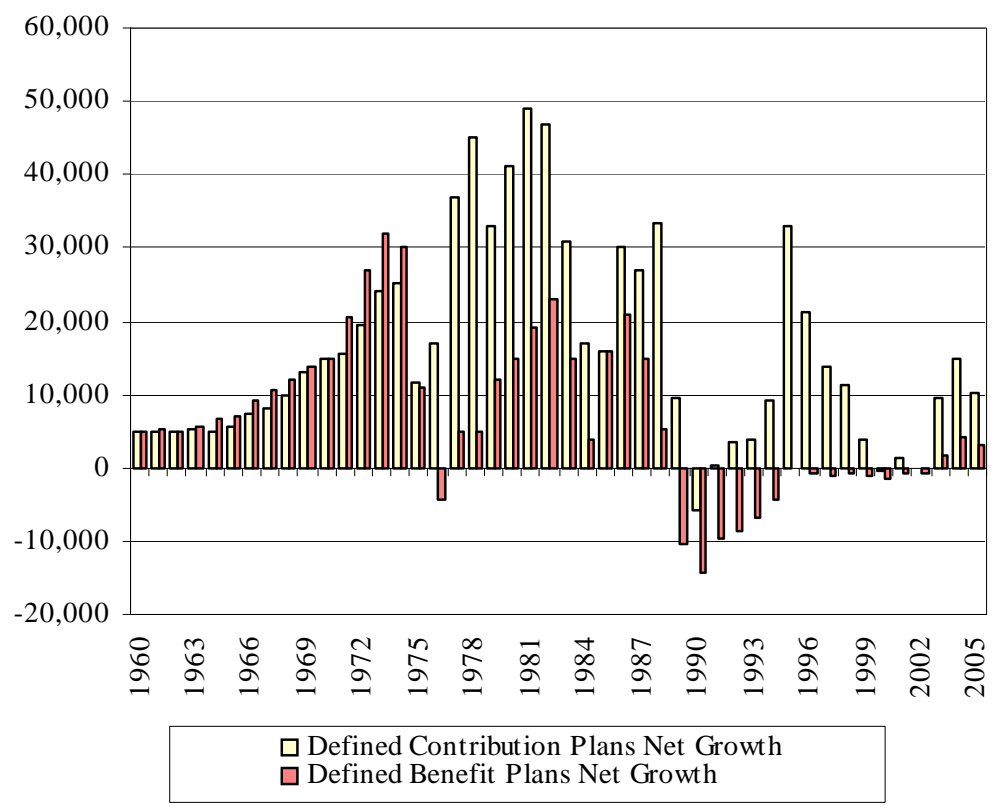

Sources: Warshawsky (1995); U.S. Internal Revenue Service (1988-2006); McGill and others (1996). 
Figure 5. Median Years of Tenure of by Age, CPS Data, 1973-2004

\section{Employed Males}
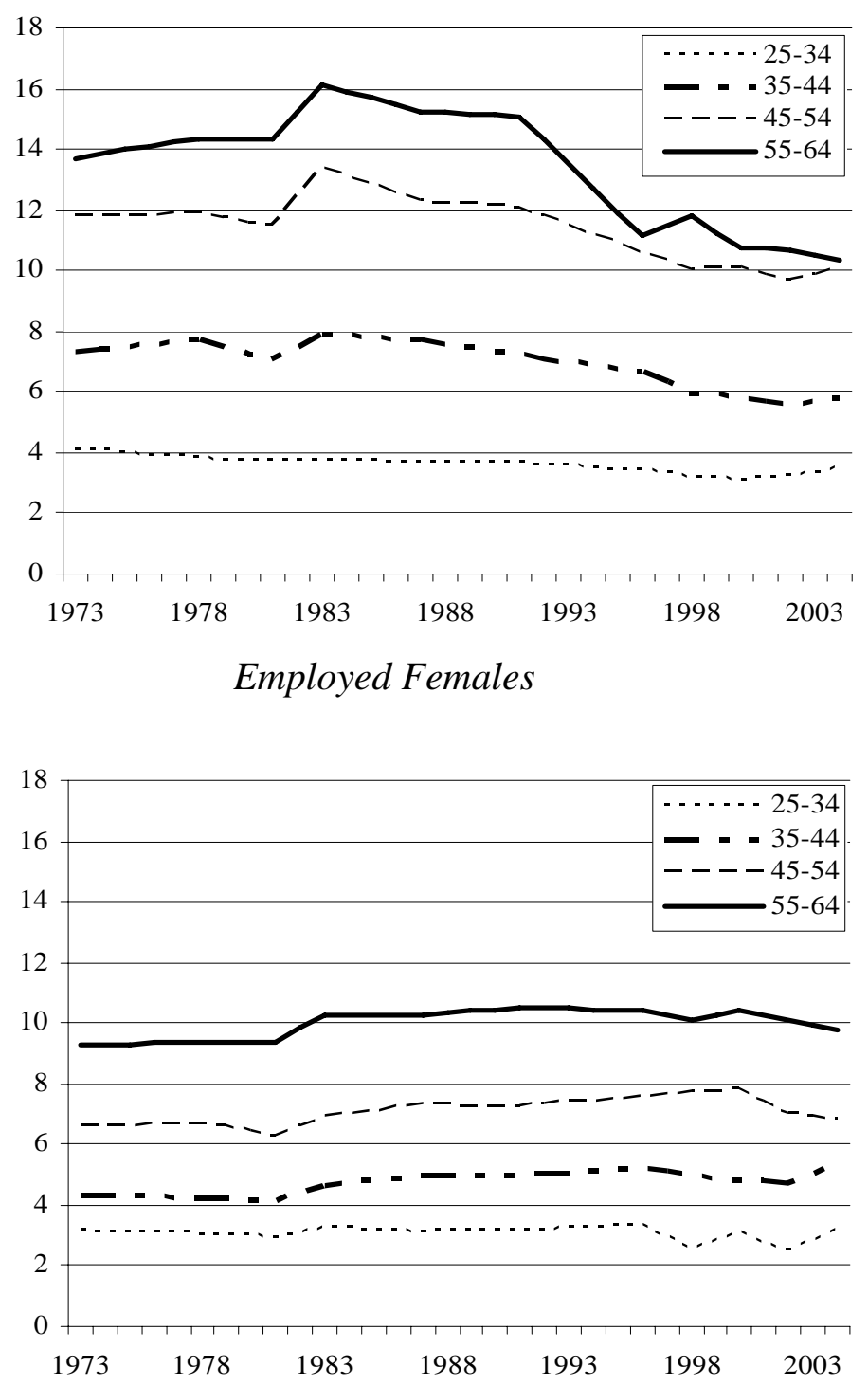

Source: Authors calculations from U.S. Bureau of the Census (1973-2004). 
Figure 6. Full-Time Workers with Age-50 Employer as a Percent of all Workers, by Age, 1973-2004

\section{Male Workers}

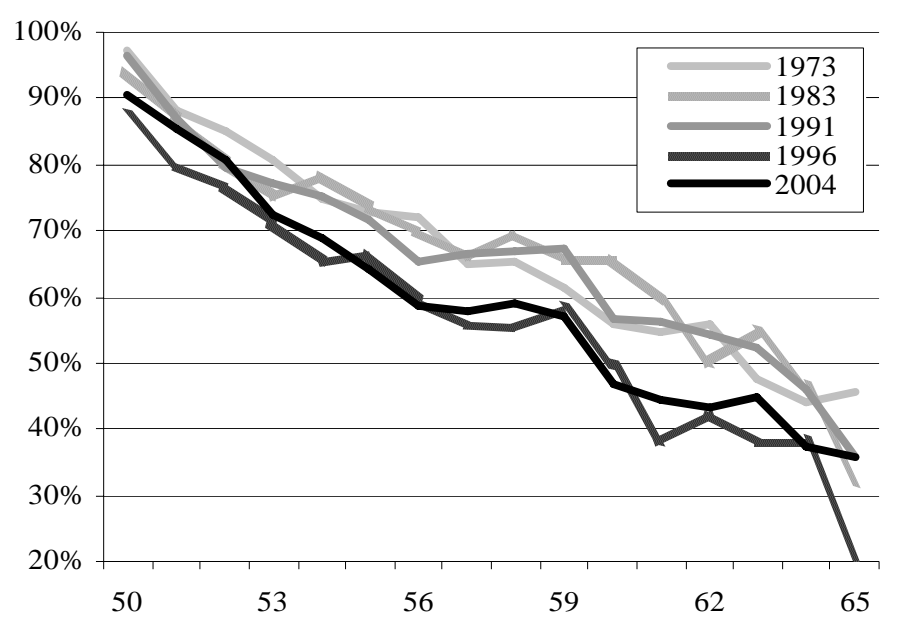

Female Workers

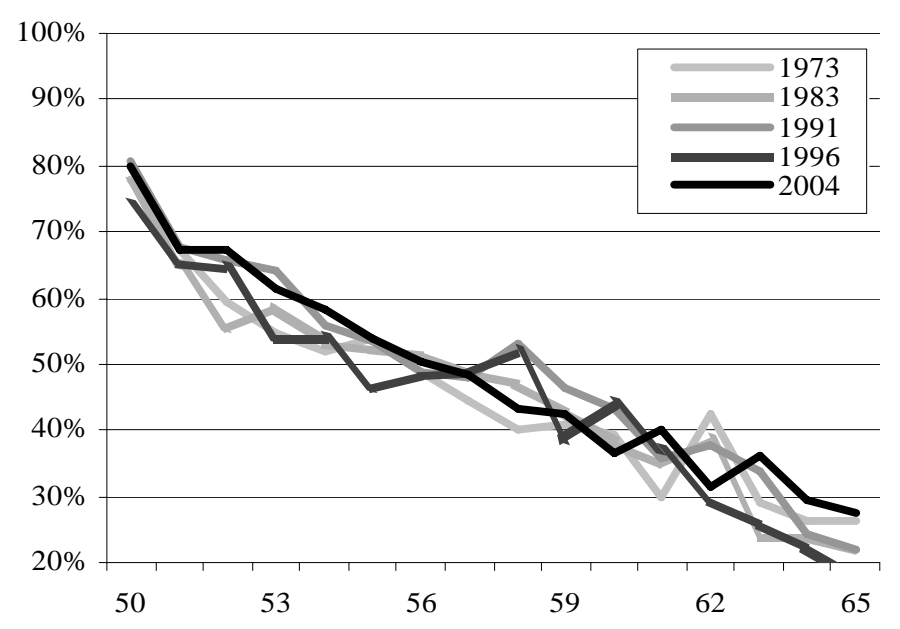

Source: Authors' calculations from U.S. Bureau of the Census (1973-2004). 
Figure 7. Median Years of Tenure by Age, SIPP Data 1973-2004

\section{Employed Males}

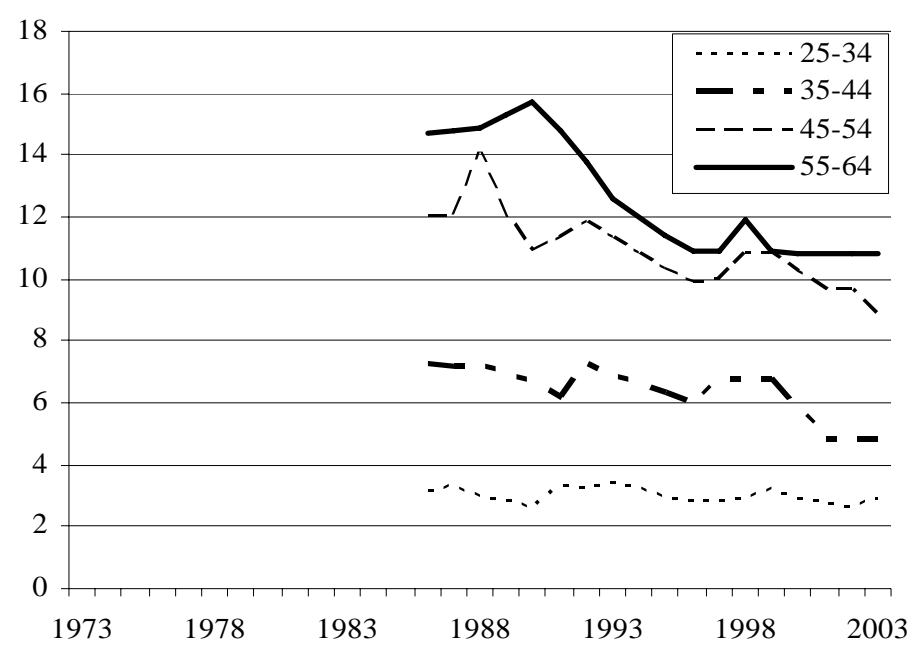

Source: Authors' calculations from U.S. Bureau of the Census (1973-2004).

\section{Employed Females}

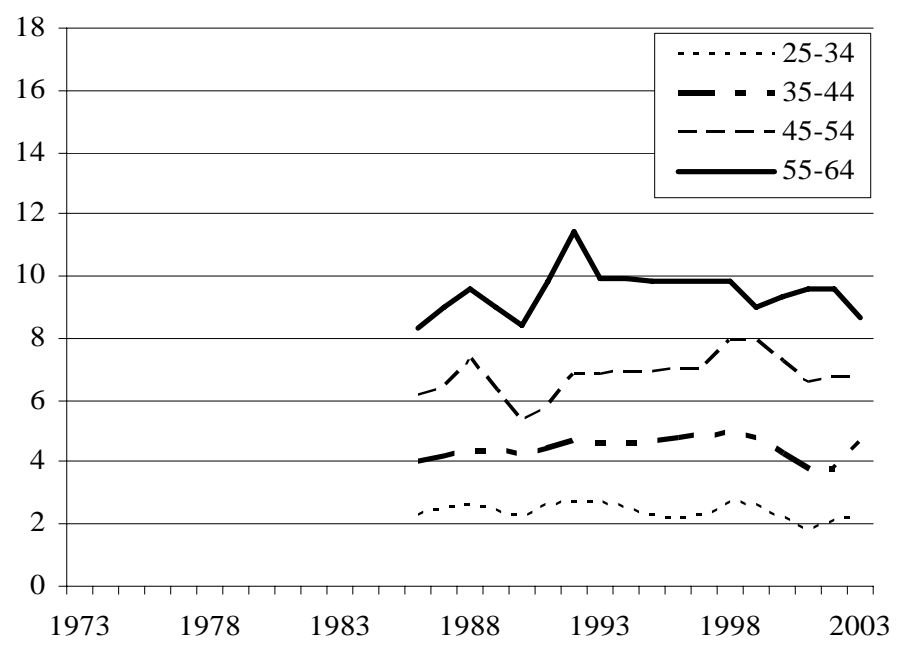

Source: Authors' calculations from U.S. Bureau of the Census (1973-2004). 
Figure 8. Number of U.S. Immigrants, 1901-2000, by Decade (Millions)

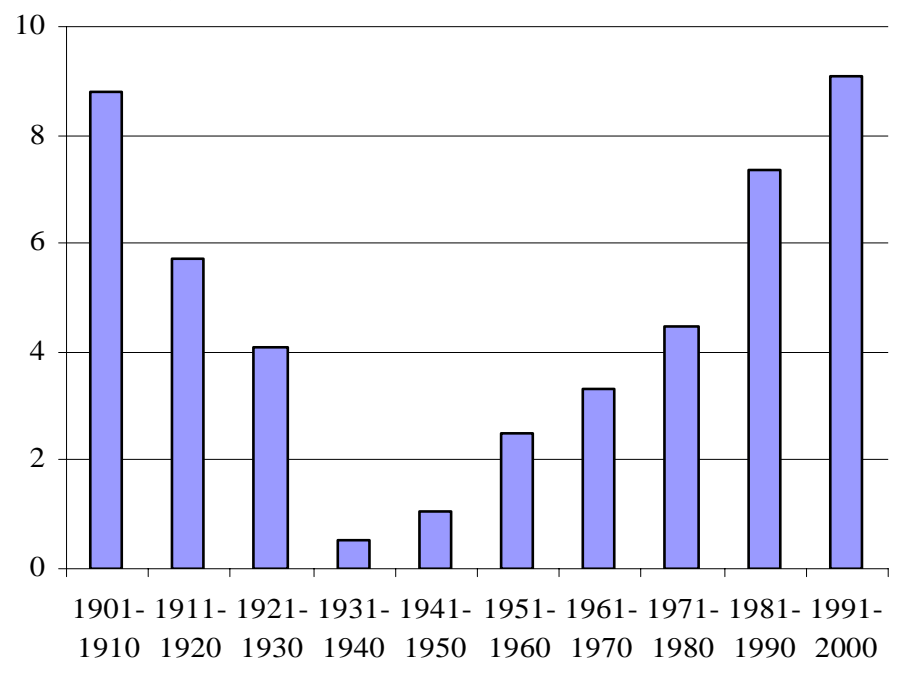

Source: U.S. Bureau of the Census (2006). 
Table A1.Estimated Four-Year Retention Rates by Tenure Group

\begin{tabular}{|c|c|c|c|c|c|c|c|c|c|}
\hline \multirow{2}{*}{$\begin{array}{l}\text { Time span } \\
\text { and initial } \\
\text { tenure group }\end{array}$} & \multicolumn{3}{|c|}{ All Ages } & \multicolumn{3}{|c|}{ Aged 45-54 } & \multicolumn{3}{|c|}{ Aged 55-64 } \\
\hline & All & Men & Women & All & Men & Women & All & Men & Women \\
\hline \multicolumn{10}{|l|}{ 1983-1987 } \\
\hline 0 to $<2$ & 0.425 & 0.451 & 0.400 & 0.642 & 0.628 & 0.655 & 0.511 & 0.485 & 0.540 \\
\hline 2 to $<9$ & 0.551 & 0.592 & 0.510 & 0.646 & 0.666 & 0.630 & 0.546 & 0.624 & 0.484 \\
\hline 9 to $<15$ & 0.773 & 0.789 & 0.751 & 0.811 & 0.795 & 0.829 & 0.474 & 0.481 & 0.468 \\
\hline $15+$ & 0.672 & 0.697 & 0.612 & 0.790 & 0.797 & 0.769 & 0.471 & 0.475 & 0.463 \\
\hline Total & 0.563 & 0.604 & 0.516 & 0.726 & 0.744 & 0.544 & 0.496 & 0.509 & 0.617 \\
\hline \multicolumn{10}{|l|}{ 1987-1991 } \\
\hline 0 to $<2$ & 0.422 & 0.435 & 0.408 & 0.590 & 0.544 & 0.631 & 0.483 & 0.472 & 0.495 \\
\hline 2 to $<9$ & 0.507 & 0.523 & 0.489 & 0.604 & 0.630 & 0.583 & 0.441 & 0.396 & 0.485 \\
\hline 9 to $<15$ & 0.742 & 0.758 & 0.723 & 0.730 & 0.799 & 0.674 & 0.486 & 0.479 & 0.493 \\
\hline $15+$ & 0.715 & 0.718 & 0.710 & 0.814 & 0.805 & 0.835 & 0.463 & 0.461 & \begin{tabular}{|l|}
0.466 \\
\end{tabular} \\
\hline Total & 0.543 & 0.567 & 0.515 & 0.695 & 0.720 & 0.665 & 0.462 & 0.448 & 0.481 \\
\hline \multicolumn{10}{|l|}{ 1991-1995 } \\
\hline 0 to $<2$ & 0.471 & 0.473 & 0.471 & 0.637 & 0.569 & 0.698 & 0.502 & 0.438 & 0.572 \\
\hline 2 to $<9$ & 0.542 & 0.555 & 0.530 & 0.628 & 0.678 & 0.589 & 0.470 & 0.416 & 0.523 \\
\hline 9 to $<15$ & 0.726 & 0.740 & 0.709 & 0.747 & 0.727 & 0.762 & 0.534 & 0.517 & 0.550 \\
\hline $15+$ & 0.685 & 0.667 & 0.717 & 0.775 & 0.747 & 0.827 & 0.420 & 0.390 & 0.471 \\
\hline Total & 0.570 & 0.581 & 0.558 & 0.700 & 0.701 & 0.698 & 0.461 & 0.418 & 0.515 \\
\hline \multicolumn{10}{|l|}{$1996-2000$} \\
\hline 0 to $<2$ & 0.347 & 0.363 & 0.330 & 0.475 & 0.516 & 0.440 & 0.412 & 0.426 & \begin{tabular}{|l|}
0.397 \\
\end{tabular} \\
\hline 2 to $<9$ & 0.507 & 0.520 & 0.492 & 0.605 & 0.609 & 0.602 & 0.485 & 0.486 & 0.484 \\
\hline 9 to $<15$ & 0.676 & 0.699 & 0.649 & 0.656 & 0.679 & 0.637 & 0.558 & 0.590 & 0.533 \\
\hline $15+$ & 0.648 & 0.651 & 0.645 & 0.690 & 0.685 & 0.698 & 0.442 & 0.451 & 0.431 \\
\hline Total & 0.497 & 0.517 & 0.474 & 0.619 & 0.635 & 0.602 & 0.467 & 0.474 & 0.460 \\
\hline \multicolumn{10}{|l|}{ 2000-2004 } \\
\hline 0 to $<2$ & 0.422 & 0.431 & 0.413 & 0.613 & 0.575 & 0.648 & 0.547 & 0.547 & 0.546 \\
\hline 2 to $<9$ & 0.552 & 0.572 & 0.531 & 0.638 & 0.664 & 0.614 & 0.546 & 0.486 & 0.613 \\
\hline 9 to $<15$ & 0.676 & 0.688 & 0.662 & 0.720 & 0.752 & 0.694 & 0.504 & 0.476 & 0.530 \\
\hline $15+$ & 0.675 & 0.681 & 0.666 & 0.740 & 0.744 & 0.735 & 0.514 & 0.534 & 0.488 \\
\hline Total & 0.545 & 0.563 & 0.525 & 0.681 & 0.693 & 0.669 & 0.526 & 0.512 & 0.542 \\
\hline
\end{tabular}

Source: Authors' calculations. 


\section{RECENT WORKING PAPERS FROM THE \\ CENTER FOR RETIREMENT RESEARCH AT BOSTON COLLEGE}

Has the Displacement of Older Workers Increased?

Alicia H. Munnell, Steven Sass, Mauricio Soto, and Natalia Zhivan, September 2006

No Place Like Home: Older Adults and their Housing

Timothy Smeeding, Barbara Boyle Torrey, Jonathan Fisher, David S. Johnson, and

Joseph Marchand, August 2006

Effects of Public Policies on the Disposition of Lump-Sum Distributions: Rational and Behavioral Influences

William G. Gale and Michael Dworsky, August 2006

Pensions, Social Security, Wealth and Lifetime Earnings: Evidence from the Health and Retirement Study

William G. Gale and John W.R. Phillips, August 2006

Determinants and Consequences of Bargaining Power in Households

Leora Friedberg and Anthony Webb, June 2006

Earnings and Women's Retirement Security

Alicia H. Munnell and Natalia Zhivan, June 2006

Mortality Heterogeneity and the Distributional Consequences of Mandatory Annuitization

Guan Gong and Anthony Webb, June 2006

Can Heterogeneity of Populations Explain Differences in Mortality?

James W. Vaupel, Roland Rau, Carlo Giovanni Camarda and Kristin G. von Kistowski, March 2006

Personalized Retirement Advice and Managed Accounts: Who Uses Them and How Does Advice Affect Behavior in 401(k) Plans?

Julie Agnew, March 2006

Working for a Good Retirement

Barbara A. Butrica, Karen E. Smith and C. Eugene Steuerle, March 2006

All working papers are available on the Center for Retirement Research website (http://www.bc.edu/crr) and can be requested by e-mail (crr@bc.edu) or phone (617-552-1762). 